\title{
Association between quality of the diet and cardiometabolic risk factors in postmenopausal women
}

\author{
Danyelle de Almeida Ventura', Vânia de Matos Fonseca ${ }^{1 *}$, Eloane Gonçalves Ramos ${ }^{1}$, \\ Lizanka Paola Figueiredo Marinheiro' ${ }^{1}$, Rita Adriana Gomes de Souza², \\ Celia Regina Moutinho de Miranda Chaves $^{1}$ and Maria Virginia Marques Peixoto ${ }^{1}$
}

\begin{abstract}
Background: Climateric is a phase of women's life marked by the transition from the reproductive to the non-reproductive period. In addition to overall weight gain, the menopause is also associated with the increase of abdominal fat. We used The Healthy Eating Index as a summary measure to evaluate the major components and the quality of women's diet after the onset of the menopause. This study aims at examining the association between the quality of the diet and cardiometabolic risk factors in postmenopausal women.
\end{abstract}

Methods: Cross-sectional study including 215 postmenopausal women attending a public outpatient clinic. The 24-hour dietary recall method was used to assess the food intake and to establish the Healthy Eating Index. Diets were then classified as appropriate diet (>80 points), diet "requiring improvement" (80-51 points), and poor diet ( $<51$ points). Cardiometabolic risk factors included abdominal obesity, dyslipidemia, diabetes mellitus, and hypertension. The Fisher's exact test was utilized for the Statistical analysis.

Results: The analysis of the food intake showed that the average daily intake of lipids (36.7\%) and sodium (2829.9 mg) were above the recommended. Only $8.8 \%$ of the women performed moderate or intense physical exercises on a regular basis. The diet was considered poor in $16.3 \%$, "requiring improvement" in $82.8 \%$, and appropriate for only $0.9 \%$ of the women. The study detected increased waist circumference in $92.1 \%$ of the participants. The mean concentration of triglycerides was of $183.3 \mathrm{mg} / \mathrm{dl}$, and $130.7 \mathrm{mg} / \mathrm{dl}$ for cholesterol (Low Density Lipoprotein).

Conclusion: Women consume a low quality diet, possibly due to the low intake of vegetables and fruits and excessive consumption of sodium. These inappropriate eating habits are associated with and, have a negative impact on the cardiometabolic risk factors such as abdominal obesity.

Keywords: Aging, Menopause, Eating habits

\section{Background}

The World Health Organization (WHO) defines climateric as a biological phase and not a pathological process, a significant period of female aging, characterized by the establishment of a physiological progressive state of hypoestrogenism, which ends with the permanent cessation of the menstrual cycles. Menopause is a mark of this phase and is acknowledged only one year after the

\footnotetext{
* Correspondence: vaniamf36@hotmail.com

'Instituto Fernandes Figueira (IFF/Fiocruz), Avenida Rui Barbosa,

716-Flamengo, Rio de Janeiro, RJ, Brazil

Full list of author information is available at the end of the article
}

occurrence of the last menstrual cycle [1]. In addition to an overall increase in body weight, menopause has been associated with a greater accumulation of abdominal fat [2]. This unfavorable change in the body fat distribution contributes to explain the increased cardiovascular risk during this stage of life [3].

The association among nutrients, food, and noncommunicable diseases (NCD) can be studied with the same tools used to assess individual food consumption, such as the 24-hour recall, which reflects the previous day of the individual food intake. The Healthy Eating Index (HEI) developed using data from the 24-hour 
dietary recall, is a summary measure of the main components of an individual's diet. It facilitates the assessment of a diet's quality, of either populations or groups of individuals. Without reducing the assessment of a single component alone, it takes into consideration the complexity of a given diet, and allows for an indirect assessment of nutrients [4].

Climateric is a topic of concern in women's health, not only for the uncomfortable symptoms it engenders, but also for its potential impact on public health. The latter includes the high prevalence of non-communicable diseases due to a new food pattern of the Brazilian population, the increased consumption of processed foods with high levels of saturated fat, sugar, and salt, in parallel with a growing elderly population [5].

Within this context, the primary purpose of this study is to verify the association between diet's quality and cardiometabolic risk factors in postmenopausal women as well as to contribute to the validation of findings in different living conditions and geographic settings.

\section{Methods}

A cross-sectional observational study consisting of a convenience sample of 234 postmenopausal women undergoing treatment at the gynecology outpatient clinic of Instituto Fernandes Figueira (IFF), within the endocrinology and urogynecology subspecialties, from October 2011 to October 2012. The inclusion criteria were: women aged $\geq 45$ years and without a menstrual period for 12 consecutive months or more. Exclusion criteria were: dietary counseling with physician or nutritionist, uncontrolled thyroid disease, special diet or vegetarian and extremely low dietary intake $(<500 \mathrm{kcal} /$ day $)$ or extremely high (>4000 kcal/day). Two hundred and fifteen women met the criteria and underwent all the required exams. The Research Ethics Committee of IFF approved this study and each participant signed a Statement of Informed Consent.

Nutritional status was estimated by The Body Mass Index $\left(\mathrm{BMI}=\right.$ weight $/$ height $\left.^{2}\right)$. Weight and height were measured with a standard beam balance scales (Filizola ${ }^{\oplus}$, Brazil) and with a stadiometer (Wiso ${ }^{\circ}$, Brazil), respectively [6,7]. The nutritional status was interpreted according to WHO recommendations. Women ( $<65$ years) were classified as normal weight $\left(18.5-24.9 \mathrm{Kg} / \mathrm{m}^{2}\right)$, as overweight $\left(25-29.9 \mathrm{Kg} / \mathrm{m}^{2}\right)$, or obese $\left(\geq 30 \mathrm{Kg} / \mathrm{m}^{2}\right)$. Elderly women ( $\geq 65$ years) as lean $\left(<22 \mathrm{Kg} / \mathrm{m}^{2}\right)$, normal weight $\left(22-27 \mathrm{Kg} / \mathrm{m}^{2}\right)$, or overweight $\left(>27 \mathrm{Kg} / \mathrm{m}^{2}\right)[8]$.

Waist circumference (WC) was measured at the midpoint between the iliac crest and the lower border of the last floating rib at the end of a normal expiration, using inelastic tape. Each measurement was duplicated and the mean value recorded. Abdominal fat was estimated indirectly by the measurement of the waist circumference, and rated high when waist $>80 \mathrm{~cm}$ [8].
We used the cutoff point of the Brazilian Society of Cardiology for adults, with isolated systolic hypertension $\geq 140 \times 90 \mathrm{mmHg}$ to classify blood pressure level [9].

Blood was collected from each subject after 12-hour fasting. These were used to determine Triglycerides (TG), total cholesterol (TC), high-density lipoprotein cholesterol (HDLC) and glucose levels. The low-density lipoprotein cholesterol (LDLC) was calculated using Friedewald et al.'s formula: LDLC = Total cholesterol - (triglycerides/ $5+$ HDLC) [10]. Normal values were: TC $<200 \mathrm{mg} / \mathrm{dl}$, HDLC $>50 \mathrm{mg} / \mathrm{dl}$, LDLC $<100 \mathrm{mg} / \mathrm{dl}$, TG $<150 \mathrm{mg} / \mathrm{dl}$ and glucose levels $<100 \mathrm{mg} / \mathrm{dl}$ [11].

Regarding lifestyle, women were classified as active (self-evaluation) or sedentary. Furthermore, this study adopted the recommendation of the Centers for Disease Control and Prevention (2008) that defines as active women those who undergo moderate or intense aerobic activity for 30 minutes at least five times a week or musclestrengthening activities two or more days per week [12].

Regarding food intake we used the acceptable macronutrient Distribution Ranges proposed in 2005 by the National Academy of Sciences being 45\%-65\% for carbohydrates, $10 \%-35 \%$ for proteins, and $20-35 \%$ for lipids of a standard total daily intake of $2000 \mathrm{Kcal}$ [13]. According to the Feeding Guidelines for the Brazilian Population, the daily intake of saturated fat, cholesterol, and sodium should be less than, $10 \%, 300 \mathrm{mg}$ and $2400 \mathrm{mg}$ respectively. In addition, the Ministry of Health recommends in the Feeding Guidelines for the Brazilian Population, a minimum daily intake of 3 servings of fruits (each serving of $70 \mathrm{kcal}$ ) and 4 servings of greeneries and vegetables (each serving of $15 \mathrm{kcal}$ ) [14].

Dietary intake data were obtained through dietary recall of each participant, with reported information on food intake over a 24-hour period preceding the interview or more often the previous day [15]. The nutritional values of food products, consumed and registered in the 24-hour dietary recall, were analysed using the Nutrition Support Programme (Nutwin, [16]). Food products that were not in the database were introduced, using the Brazilian Food Composition Tables (TACO, [17]) and Pinheiro et al. [18]. The data on food intake were used to calculate the HEI scores. The HEI comprises ten components being five food groups (cereal, breads, roots and tubers; fruits and vegetables; milk and dairy products; meat, eggs and beans), four nutrients (saturated fat, total fat, cholesterol, and sodium), plus a measure of dietary variety. Each of ten components contributes with 10 points to the maximum possible score of 100 [19].

The servings of the food follow the daily recommendation of the Feeding Guide for the Brazilian Population as per $1000 \mathrm{Kcal}$. Based on the total energy calculated by adding up all items of a given food group, we calculated the number of consumed portions of this group, based 
on the energy content of a defined portion [20]. Each component of the HEI had a score from zero to ten, and intermediate values were recorded as a proportion of the consumption by group. Thus, ten points, would be scored if the consumption in the group of cereals, breads, tubers and roots was of 450/1000 kcal. Likewise for the group of greenery and vegetables, $22.5 / 1000 \mathrm{kcal}$ and the fruits group 105/1000 kcal. The same for the consumption of milk and dairy products $180 / 1000 \mathrm{kcal}$ and the meat, eggs and beans 122.5/1000 kcal. The calculation of all other components followed the same rational being total fat $<30 \%$; saturated fat $<10 \%$; cholesterol $<300 \mathrm{mg} /$ day, sodium $\leq 2,4 \mathrm{mg} /$ day, and the variety in the diet characterized by the consumption of 8 or more different types of food daily [21]. According to the final score, the consumption was classified as "poor" diet (HEI <51 points), diet "requiring improvement" (HEI between 51 and 80 points), and healthy diet (HEI $>80$ points) [19].

The data was stored with double entry on access database and processed by a software developed in $\mathrm{R}$ language and the statistical analysis performed with the Statistical Package for Social Sciences software - SPSS, version 13. The continuous variables depicted by measures of central tendency (mean or median), scatter plot, and of minimum and maximum values. For the comparison of categorical variables, the Fisher's exact test or they Chi-squared test were used with $\alpha=0.05$ for statistical significance and $95 \%$ confidence interval.

\section{Results and discussion}

Table 1 shows the main characteristics of the study group. Median age was 58.9 years and median age at menopause 49.0 years. Regarding the pattern of food consumption, the results of this study are analogous to those reported by Tardivo et al. [21] on the association between diet quality and metabolic risk indicators in postmenopausal women in the state of São Paulo. The median HEI scores was 60.0 and the total daily calorie intake averaged $1607.8 \mathrm{Kcal}$ showed by these authors were close to our findings, respectively 60.7 for HEI scores and $1619.4 \mathrm{Kcal}$ (Table 1). The participants of this study consumed a slightly higher percentage of protein (median 17.3 versus $15.4 \%$ ), and carbohydrates (49.9 versus $46.0 \%$ ), but a lower consumption of lipids (35.6 versus 38.3\%). Most women surveyed consumed either a diet "requiring improvement" $(82.8 \%)$ or poor $(16.3 \%)$, and only $0.9 \%$ ate an adequate diet. Tardivo et al. also showed a similar pattern regarding poor diet and requiring improvement (48.5\%), with an adequate diet recorded for 3\% of women [21].

The vast majority $(94.9 \%)$ reported a protein intake within the recommended limits and it did not account significantly to the quality of the diet (Table 2) as opposed to Tardivo's study where all macronutrients contributed significantly to determining the quality of the diet
Table 1 Clinical characteristics, laboratory values, dietary intakes and Healthy Eating Index score

\begin{tabular}{|c|c|c|c|}
\hline Characteristics & Average & $\begin{array}{c}\text { Median } \\
(\text { P25; P75)* }\end{array}$ & Range $^{* *}$ \\
\hline \multicolumn{4}{|l|}{ Sociodemographic } \\
\hline Age (years) & 59.3 & $58.9(53.4 ; 64.6)$ & $44.5-90.1$ \\
\hline Education (years) & 5.85 & $8(4.0 ; 8.0)$ & $0-8$ \\
\hline $\begin{array}{l}N^{0} \text { of people living in the } \\
\text { house }\end{array}$ & 2.88 & $3(2.0 ; 4.0)$ & $1-8$ \\
\hline Per capita income (R\$) & 1678.5 & $1240(850 ; 2000)$ & $300-12000$ \\
\hline \multicolumn{4}{|l|}{ Outpatient clinics } \\
\hline $\begin{array}{l}\text { Age at Menopause } \\
\text { (years) }\end{array}$ & 47.2 & $49(44 ; 51)$ & $30-60$ \\
\hline $\begin{array}{l}\text { Length of menopause } \\
\text { (years) }\end{array}$ & 12.0 & $10.7(5.5 ; 17.2)$ & $0.8-34.3$ \\
\hline $\mathrm{BMI}\left(\mathrm{Kg} / \mathrm{m}^{2}\right)$ & 28.3 & $28.0(24.6 ; 31.6)$ & $18.1-42.5$ \\
\hline WC (cm) & 95.4 & $94.7(87.3 ; 103)$ & $65-134$ \\
\hline $\begin{array}{l}\text { Diastolic blood pressure } \\
(\mathrm{mmHg})\end{array}$ & 81.5 & $80(70 ; 90)$ & $60-140$ \\
\hline $\begin{array}{l}\text { Systolic blood pressure } \\
(\mathrm{mmHg})\end{array}$ & 131.2 & $130(120 ; 140)$ & $90-260$ \\
\hline \multicolumn{4}{|l|}{ Lifestyle } \\
\hline $\begin{array}{l}\text { Exercises leisure } \\
\text { (minutes/week) }\end{array}$ & 256.1 & $225(120 ; 300)$ & $20-900$ \\
\hline \multicolumn{4}{|l|}{ Inflammatory markers } \\
\hline Glucose levels (mg/dL) & 111.9 & $103(94 ; 117)$ & $66-469$ \\
\hline $\mathrm{TC}(\mathrm{mg} / \mathrm{dl})$ & 222.3 & $218(196 ; 250)$ & $91-336$ \\
\hline LDLC (mg/dl) & 130.7 & $128(106 ; 154)$ & $63-246$ \\
\hline HDLC (mg/dl) & 55.7 & $55(46 ; 64)$ & $29-100$ \\
\hline $\mathrm{TG}(\mathrm{mg} / \mathrm{dl})$ & 183.3 & $165(120 ; 220)$ & $60-558$ \\
\hline \multicolumn{4}{|l|}{ Food Intake } \\
\hline Total energy value (kcal/d) & 1737.8 & $1619.4(1286.1 ; 2041.2)$ & $698.8-3955.3$ \\
\hline Protein (\%) & 18.2 & $17.3(14.2 ; 21.6)$ & $8.1-44.5$ \\
\hline Carbohydrate (\%) & 48.8 & $49.9(41.5 ; 56.0)$ & $14.6-73.6$ \\
\hline Lipids (\%) & 36.7 & $35.6(30.2 ; 41.7)$ & $16.6-68.2$ \\
\hline Saturated Fat (\%) & 10.3 & $9.8(7.8 ; 12.7)$ & $3.1-25.2$ \\
\hline Cholesterol (mg) & 230.5 & $178.2(122.8 ; 282.3)$ & $14.7-989.8$ \\
\hline Sodium (mg) & 2829.9 & $2521.5(1843.5 ; 3603,8)$ & $530.5-10596.2$ \\
\hline HEl (score) & 60.3 & $60.7(54.2 ; 66.9)$ & $33.0-84.2$ \\
\hline
\end{tabular}

*Data are expressed as median with 25th and 75th percentiles in parentheses. **Values minimum-maximum.

[21]. Regarding women who consumed a poor diet our results are comparable to their findings as to higher consumption of calories, lipids, saturated fat, cholesterol and sodium, as well as carbohydrates below the recommended intake (Table 2).

When evaluating the mean quality scores separately for each component of the HEI, the worst records relate to the fruits and greeneries and, the vegetables groups (Table 3). The group of meat, eggs and beans stood out as the best score, possibly linked to the daily consumption of beans, a 
Table 2 Association between Healthy Eating Index scores and clinical characteristics, inflammatory markers and dietary intake

\section{Characteristics \\ Outpatient clinics \\ Hormone therapy}

$$
\text { Yes }
$$

No

$\mathrm{BMI}<65$ years old

$$
\begin{aligned}
& \text { Eutrophic } \\
& \text { Overweight }
\end{aligned}
$$

Obese

$\mathrm{BMI} \geq 65$ years old

$$
\text { Lean }
$$

Overweight

WC (cm)

$$
\begin{aligned}
& <80 \\
& \geq 80
\end{aligned}
$$

High blood pressure

$$
\text { Yes }
$$

No

Self-reported lifestyle

Active

Sedentary

Aerobic exercises

Yes

No

Strengthening exercises

$$
\text { Yes }
$$$$
\text { No }
$$

\section{Inflammatory markers}

Glucose levels (mg/dL)

$$
\begin{aligned}
& <100 \\
& \geq 100
\end{aligned}
$$

$\mathrm{TC}(\mathrm{mg} / \mathrm{dl})$

$\begin{array}{lc}<200 & 60(27.9 \%) \\ \geq 200 & 155(72.1 \%)\end{array}$

$\operatorname{LDLC}(\mathrm{mg} / \mathrm{dl})$

$\begin{array}{lc}<100 & 40(18.6 \%) \\ \geq 100 & 175(81.4 \%)\end{array}$

$\mathrm{HDLC}(\mathrm{mg} / \mathrm{dl})$

$<50$

$75(34.9 \%)$

$\geq 50$

140 (65.1\%)

TG (mg/dl)

$$
<150
$$$$
88 \text { (40.9\%) }
$$$$
\geq 150
$$

17 (7.9\%)

$68(31.6 \%)$

127 (59.1\%)
0.57

$$
\begin{gathered}
3(10.0 \%) \\
32(17.3 \%)
\end{gathered}
$$

27 (90.0\%)

0 (0\%)

151 (81.6\%)

$2(1.1 \%)$

0.45

$$
\begin{gathered}
5(10.4 \%) \\
13(20.6 \%)
\end{gathered}
$$

11 (19.6\%)

0.15

$$
\begin{gathered}
0(0 \%) \\
0(0 \%) \\
6(20.7 \%)
\end{gathered}
$$

43 (89.6\%)

0 (0\%)

49 (77.8\%)

1 (1.6\%)

44 (78.6\%)

$1(1.8 \%)$

0.78

$2(11.8 \%)$

33 (16.7\%)

5 (100.0\%)

$0(0 \%)$

14 (100.0\%)

$0(0 \%)$

23 (79.3\%)

$0(0 \%)$

$198(92.1 \%)$

0.38

14 (20.6\%)

21 (14.3\%)

0.09

$9(12.7 \%)$

15 (88.2\%)

0 (0\%)

163 (82.3\%)

2 (1.0\%)

54 (79.4\%)

0 (0\%)

124 (84.4\%)

$2(1.4 \%)$

$60(84.5 \%)$

$2(2.8 \%)$

26 (18.1\%)

118 (81.9\%)

$0(0 \%)$

0.81

2 (14.3\%)

11 (78.6\%)

$1(7.1 \%)$

2 (8.0\%)

22 (88.0\%)

1 (4.0\%)

0.58

1 (20.0\%)

4 (80.0\%)

$0(0 \%)$

3 (8.8\%)

$29(85.3 \%)$

2 (5.9\%)

0.73

14 (17.5\%)

66 (82.5\%)

$0(0 \%)$

21 (15.6\%)

112 (83.0\%)

2 (1.5\%)

0.27

$13(21.7 \%)$

22 (14.2\%)

47 (78.3\%)

0 (0\%)

131 (84.5\%)

$2(1.3 \%)$

0.75

$$
5 \text { (12.5\%) }
$$

35 (87.5\%)

$0(0 \%)$

30 (17.1\%)

143 (81.7\%)

$2(1.1 \%)$

0.37

$$
15 \text { (20.0\%) }
$$

60 (80.0\%)

$0(0 \%)$

20 (14.3\%)

118 (84.3\%)

$2(1.4 \%)$

0.58
$13(14.8 \%)$

75 (85.2\%)

$0(0 \%)$

$103(81.1 \%)$

$2(1.6 \%)$ 


\begin{tabular}{|c|c|c|c|c|c|}
\hline \multicolumn{6}{|l|}{ Food intake } \\
\hline Total energy intake (kcal/day) & & $<0.001$ & & & \\
\hline$<2000$ & $160(74.4 \%)$ & & $10(6.3 \%)$ & $148(92.5 \%)$ & $2(1.3 \%)$ \\
\hline$\geq 2000$ & $55(25.6 \%)$ & & $25(45.5 \%)$ & $30(54.5 \%)$ & $0(0.0 \%)$ \\
\hline Protein (\%) & & 0.21 & & & \\
\hline$<10$ & $7(3.3 \%)$ & & $0(0.0 \%)$ & $7(100.0 \%)$ & $0(0.0 \%)$ \\
\hline $10-35$ & $204(94.9 \%)$ & & $33(16.2 \%)$ & $169(82.8 \%)$ & $2(1.0 \%)$ \\
\hline$>35$ & $4(1.9 \%)$ & & $2(50.0 \%)$ & $2(50.0 \%)$ & $0(0.0 \%)$ \\
\hline Carbohydrate (\%) & & 0.001 & & & \\
\hline$<45$ & $77(35.8 \%)$ & & $20(26.0 \%)$ & $57(74.0 \%)$ & $0(0.0 \%)$ \\
\hline $45-65$ & $129(60.0 \%)$ & & $15(11.6 \%)$ & $112(86.8 \%)$ & $2(1.6 \%)$ \\
\hline$>65$ & $9(4.2 \%)$ & & $0(0.0 \%)$ & $9(100.0 \%)$ & $0(0.0 \%)$ \\
\hline Lipids \% & & 0.001 & & & \\
\hline$<20$ & $7(3.3 \%)$ & & $0(0.0 \%)$ & $7(100.0 \%)$ & $0(0.0 \%)$ \\
\hline $15-30$ & $94(43.7 \%)$ & & $4(4.3 \%)$ & $88(93.6 \%)$ & $2(2.1 \%)$ \\
\hline$>30$ & $114(53.0 \%)$ & & $31(27.2 \%)$ & $83(72.8 \%)$ & $0(0.0 \%)$ \\
\hline Saturated fat (\%) & & $<0.001$ & & & \\
\hline$<10$ & $111(51.6 \%)$ & & $9(8.1 \%)$ & $100(90.1 \%)$ & $2(1.8 \%)$ \\
\hline$\geq 10$ & $104(48.4 \%)$ & & $26(25.0 \%)$ & $78(75.0 \%)$ & $0(0.0 \%)$ \\
\hline Cholesterol (mg) & & $<0.001$ & & & \\
\hline$\leq 300$ & $168(78.1 \%)$ & & $14(8.3 \%)$ & $152(90.5 \%)$ & $2(1.2 \%)$ \\
\hline$>300$ & $47(21.9 \%)$ & & $21(44.7 \%)$ & $26(55.3 \%)$ & $0(0.0 \%)$ \\
\hline Sodium (mg) & & $<0.001$ & & & \\
\hline$\leq 2400$ & $96(44.7 \%)$ & & $4(4.2 \%)$ & $91(94.8 \%)$ & $1(1.0 \%)$ \\
\hline$>2400$ & $119(55.3 \%)$ & & $31(26.1 \%)$ & $87(73.1 \%)$ & $1(0.8 \%)$ \\
\hline Vegetables and greenery intake & & 0.1 & & & \\
\hline$\geq 4$ servings & $23(10.7 \%)$ & & $5(21.7 \%)$ & $17(73.9 \%)$ & $1(4.3 \%)$ \\
\hline$<4$ servings & $192(89.3 \%)$ & & $30(15.6 \%)$ & $161(83.9 \%)$ & $1(0.5 \%)$ \\
\hline Fruit Intake & & 1 & & & \\
\hline$\geq 3$ servings & $2(0.9 \%)$ & & $0(0.0 \%)$ & $2(100.0 \%)$ & $0(0.0 \%)$ \\
\hline$<3$ servings & $213(99.1 \%)$ & & $35(16.4 \%)$ & $176(82.6 \%)$ & $2(0.9 \%)$ \\
\hline
\end{tabular}

Data are expressed in numbers and percentage between parentheses.

${ }^{a}$ statistical difference between groups $p<0.05$ (Fisher's Exact Test).

${ }^{\mathrm{b}} \mathrm{HEI}<51$ points.

${ }^{\mathrm{C}} \mathrm{HEl}$ between 51 and 80 points.

${ }^{\mathrm{d}} \mathrm{HEI}>80$ points.

typical and vital component of the Brazilian diet. These findings are in agreement with the results of the Household Budget Survey (POF 2008-2009), which showed a profile of food consumption that combines traditional Brazilian diet of rice and beans with foods that are high in calories with low content of nutrients and, well below the recommended intake for fruits, greeneries and vegetables [22].

Levy Costa et al. reported an evolving change of food availability, distribution and food intake patterns at the household and population levels since the 70's, leading to the current profile. Their findings are consistent with the rising prevalence of overweight and obesity and the increasing rate of NCDs and their contribution to the morbidity and mortality profiles of the population. This diet configuration, called "western" or "westernized" includes a high intake of salt and sugar, a reduced consumption of fruits, fiber and vegetables and an increased level of total and saturated fats [23].

Pereira et al. compared the food consumption of women aged 35 or more in two population based cross sectional 
Table 3 Mean, median, minimum and maximum score of the Healthy Eating Index components

\begin{tabular}{ccccc}
\hline HEI components & Mean & Median & Score Min & Score Max \\
\hline Cereal, bread, tubers, roots & 3.96 & 3.77 & $0.52(0.5)$ & $9.8(0.5)$ \\
Vegetables and greenery & 2.13 & 0.00 & $0(67.4)$ & $10(10.7)$ \\
Fruits & 1.83 & 1.39 & $0(1.9)$ & $10(0.9)$ \\
Milk and dairy & 4.87 & 4.52 & $0(9.8)$ & $10(17.2)$ \\
Meat, eggs and legumes & 10.0 & 10.0 & $9.0(0.5)$ & $10(99.5)$ \\
Total fat & 5.57 & 6.20 & $0(19.5)$ & $10(24.7)$ \\
Saturated fat & 7.29 & 10.0 & $0(10.2)$ & $10(51.6)$ \\
Cholesterol & 8.47 & 10.0 & $0(11.6)$ & $10(78.1)$ \\
Sodium & 7.33 & 9.49 & $0(7.9)$ & $10(44.7)$ \\
Variety of diet & 8.90 & 10 & $2.0(1.9)$ & $10(65.6)$ \\
Diet quality index & 60.3 & 60.7 & $33.0(0.5)$ & $84.2(0.5)$ \\
\hline
\end{tabular}

Data are expressed as number and percentage in parentheses.

studies undertook in Rio de Janeiro, Brasil, in 1995-1996 $(\mathrm{n}=1.014)$ e 2004-2005 $(\mathrm{n}=1.001)$. The prevalence of obesity (BMI $\geq 30 \mathrm{~kg} / \mathrm{m} 2$ ) raised from $16.6 \%$ para $24 \%$ in 10 years. Pereira et al. also show that changes in dietary intake of adult women in the Metropolitan Region of Rio de Janeiro are in disagreement with the recommendations for healthy eating. There was an increase in the consumption of processed foods with high-energy and there was a decrease in the consumption of fruits, milk, beans, roots, tubers and meats. In this population group, the shift from the traditional Brazilian food habits is detrimental to the overall quality of diets and possibly contributes to the occurrence of overweight and obesity. There is also an increased risk of developing metabolic disorders and other non-communicable chronic diseases [24]. Most women of this study had an inadequate consumption of fruits (99.1\%) and of greeneries and vegetables $(89,3 \%)$ (Table 2). There was a significant association between high concentrations of LDL-cholesterol and lower fruit intake (Table 4). Hung et al. assessed the association between fruit intake and cardiovascular disease, fruits being protective when consumption was of $\geq 3$ fruit servings per day [25].

Another study found that low intake of fruits represented both, overall risk for obesity and for abdominal fat Perozzo et al. [26] studied the association between food patterns and obesity in a population based cross sectional study, with a representative sample of 1.026 women (20-60 years) in São Leopoldo, Rio Grande do Sul, Brazil. Overall and abdominal obesity were present in $18 \%$ and $23.3 \%$ women respectively. After controlling for confounding factors, low fruit intake was positively associated with BMI [26]. The present study did not find such an association.

Identifying the type of body fat distribution is crucial because the accumulation of fat in the abdominal region is directly linked to metabolic changes that can lead to the development of cardiovascular diseases and diabetes mellitus. During the menopause, the decrease in estrogen and the overall increase of body weight are concurrent with the augmentation of visceral fat (abdominal). This characterizes an android profile associated with higher cardiovascular risks in postmenopausal women [27]. Toth et al. reported a $49 \%$ increase in abdominal fat and $22 \%$ of subcutaneous fat in postmenopausal women compared to women between the first and last natural menstruation [2].

In this study, the prevalence of high WC as a cardiometabolic risk factor was high $(92.1 \%)$, as well as glucose levels (62.8\%) and triglycerides (59.1\%) (Table 2). Cardiometabolic risk factors and diet quality are not significantly associated in this study (Table 2), corroborating the findings reported by Tardivo et al. [21]. These authors also found an association between diet quality and total body fat estimated by skinfold, a measurement not collected measurement in the present study. Nonetheless, this study showed that women under 65 and overweight have a higher prevalence of hypertension and hyperglycemia and that the excessive intra-abdominal fat relates to glucose intolerance and insulin resistance (Table 5).

The high WC as surrogate measure for the accumulation of intra-abdominal fat, is directly associated with the prevalence of diabetes, increasing the risk of cardiovascular disease. Before menopause, women have lower levels of blood pressure than men of the same age group do. After menopause, the blood pressure levels of women exceed those of men in the same age range. Hypoestrogenism during the postmenopause causes a tendency to increase blood pressure thus increasing the risk of cardiovascular diseases [1].

The mean daily sodium intake was of $2829.9 \mathrm{mg}$ (Table 1), is above the maximum recommended intake for adults (2400 mg) [14] and less than that reported by the Research Project on Household Budgets (POF) 2008-2009 (12 g of salt or $4700 \mathrm{mg}$ of sodium) [22]. Women (7\%) also reported adding salt to prepared meals. Being aware that this is quite a popular practice, we may consider this figure underrated. Martinazzo et al. reported a prevalence of $16.7 \%$ of excessive sodium intake, which is roughly 2.4 fold higher than the level found in this study [28]. However, this level of excessive sodium intake was associated with higher serum concentrations of total cholesterol and LDLC, increased lipids and dietary cholesterol, and even lack of hormone replacement therapy (Table 4). The profile of inadequate dietary intake of sodium and lipids is associated with lower levels of estrogens and favors atherogenesis. Along the aging process, women experience variations in their metabolic profile leading to changes in the composition and distribution of adipose 
Table 4 Association between inadequate intake with clinical characteristics, inflammatory markers and food intake (Continued)

Lipids (\%)

p-value
$<20$
$20-30$
$>30$

$\begin{array}{cc} & 0.53 \\ 7(3.3 \%) & 7(100.0 \%) \\ 94(43.7 \%) & 94(100.0 \%) \\ 114(53.0 \%) & 112(98.2 \%)\end{array}$

0.29

0.01

Saturated Fat (\%)

\begin{tabular}{|c|c|}
\hline$p$-value & \\
\hline$<10$ & $111(51.6 \%)$ \\
\hline
\end{tabular}

$$
\begin{aligned}
& 7(100.0 \%) \\
& 87(92.6 \%)
\end{aligned}
$$

$47(50.0 \%)$

$98(86.0 \%)$

$71(62.3 \%)$

\begin{tabular}{|c|c|c|c|c|}
\hline p-value & & 0.06 & $<0.001$ & $<0.001$ \\
\hline$\geq 300$ & 168 (78.1\%) & $166(98.8 \%)$ & $161(95.8 \%)$ & 83 (49.4\%) \\
\hline$>300$ & 47 (21.9\%) & 47 (100.0\%) & 31 (66.0\%) & 36 (76.6\%) \\
\hline
\end{tabular}

holesterol (mg)

Data are expressed in numbers and percentage between parentheses.

*statistical difference between groups $p<0.05$ (Fisher's Exact Test).

\begin{tabular}{|c|c|c|c|c|c|c|}
\hline Characteristics & $\mathrm{N}($ Total = 215) & $\begin{array}{l}\text { Increased WC } \\
(\geq 80 \mathrm{~cm})\end{array}$ & $\begin{array}{l}\text { Low HDL } \\
(<50 \mathrm{mg} / \mathrm{dl})\end{array}$ & $\begin{array}{l}\text { Increased TG } \\
(\geq 150 \mathrm{mg} / \mathrm{dl})\end{array}$ & $\begin{array}{c}\text { High blood pressure } \\
(\geq 130 \times 85 \mathrm{mmHg})\end{array}$ & $\begin{array}{c}\text { Increased glucose levels } \\
(\geq 100 \mathrm{mg} / \mathrm{dl})\end{array}$ \\
\hline \multicolumn{7}{|l|}{ Outpatient clinics } \\
\hline \multicolumn{7}{|l|}{ BMI <65 years old } \\
\hline p-value* & & $<0.001$ & 0.25 & 0.42 & 0.03 & 0.01 \\
\hline Eutrophic & $48(28.7 \%)$ & $36(75.0 \%)$ & 19 (39.6\%) & $25(52.1 \%)$ & $9(18.8 \%)$ & $22(45.8 \%)$ \\
\hline Overweight & $63(37.7 \%)$ & $62(98.4 \%)$ & $19(30.2 \%)$ & $39(61.9 \%)$ & $21(33.3 \%)$ & $44(69.8 \%)$ \\
\hline Obese & $56(33.6 \%)$ & $56(100.0 \%)$ & $25(44.6 \%)$ & $36(64.3 \%)$ & $24(42.9 \%)$ & $39(69.6 \%)$ \\
\hline \multicolumn{7}{|c|}{$\mathrm{BMI} \geq 65$ years old } \\
\hline p-value* & & $<0.001$ & 0.12 & 0.47 & 0.71 & 0.24 \\
\hline Lean & $5(10.4 \%)$ & $3(60.0 \%)$ & $1(20.0 \%)$ & $3(60.0 \%)$ & $1(20.0 \%)$ & $4(80.0 \%)$ \\
\hline Eutrophic & $14(29.2 \%)$ & $12(85.7 \%)$ & $1(7.1 \%)$ & $6(42.9 \%)$ & $3(21.4 \%)$ & $6(42.9 \%)$ \\
\hline Overweight & $29(60.4 \%)$ & $29(100.0 \%)$ & $10(34.5 \%)$ & $18(62.1 \%)$ & $10(34.5 \%)$ & $20(69.0 \%)$ \\
\hline \multicolumn{7}{|l|}{ Lifestyle } \\
\hline \multicolumn{7}{|c|}{ Self-reported lifestyle } \\
\hline p-value* & & 0.51 & 0.24 & 0.09 & 0.49 & 0.39 \\
\hline Active & $71(33.0 \%)$ & $65(91.5 \%)$ & $22(31.0 \%)$ & $37(52.1 \%)$ & $23(32.4 \%)$ & $46(64.8 \%)$ \\
\hline Sedentary & $144(67.0 \%)$ & $133(92.4 \%)$ & $53(36.8 \%)$ & $90(62.5 \%)$ & $45(31.3 \%)$ & $89(61.8 \%)$ \\
\hline \multicolumn{7}{|l|}{ Aerobic exercises } \\
\hline p-value* & & 0.64 & 0.2 & 0.48 & 0.06 & 0.52 \\
\hline Yes & $14(6.5 \%)$ & $11(78.6 \%)$ & $2(14.3 \%)$ & $7(50.0 \%)$ & $2(14.3 \%)$ & $10(71.4 \%)$ \\
\hline No & $25(11.6 \%)$ & $22(88.0 \%)$ & $8(32.0 \%)$ & $14(56.0 \%)$ & $11(44.0 \%)$ & $19(76.0 \%)$ \\
\hline \multicolumn{7}{|c|}{ Strengthening exercises } \\
\hline p-value* & & 0.16 & 0.2 & 0.12 & 0.45 & 0.38 \\
\hline Yes & $5(2.3 \%)$ & $3(60.0 \%)$ & $0(0.0 \%)$ & $1(20.0 \%)$ & $1(20.0 \%)$ & $3(60.0 \%)$ \\
\hline No & 34 (15.8\%) & 30 (88.2\%) & 10 (29.4\%) & 20 (58.8\%) & $12(35.3 \%)$ & $26(76.5 \%)$ \\
\hline
\end{tabular}

Table 5 Association between cardiometabolic risk factors and clinical characteristics 
tissue, favoring not only weight gain, but also the progression of atherosclerotic processes. Estrogen deficiency is not the only predisposing factor for weight gain after menopause. It is often parallel to lower basal metabolic rate and a tendency to adopt a more sedentary lifestyle, subsequent to the aging process [29].

The risk of developing coronary artery disease related to sedentary life is 1.5 to 2.4 times higher when compared to hypertension, dyslipidemia and smoking. Aerobic physical activity of moderate intensity when performed on a regular basis (at least 30 minutes, three times a week), can have an impact in reducing the risk of cardiovascular events in the range $30-40 \%$ [11]. In this study, although $33 \%$ of women are self-reported as active (Table 2) and $74.4 \%$ consumed a normal caloric diet (less than $2000 \mathrm{kcal} /$ day), there is a high prevalence of overweight and obesity as well as high WC. Only $8.8 \%$ actually performed aerobic or strengthening exercises sufficiently enough to have an impact on the prevention of cardiovascular diseases [12]. Women who do not perform physical activities were more likely to have high blood pressure (44\%) when compared to those who were active (14.3\%) (Table 5). Regular physical activities is an important therapeutic, non-pharmacological preventive method against cardiovascular events.

The following study limitations are important when interpreting the findings reported herein. First, the sample size was relatively small due to the type of the study design (cross-sectional study, based on a convenience sample). Thus, the study results do not reflect either the nutritional status, or the health patterns of the population of Rio de Janeiro. Second, the variation of food consumption exists between individuals (inter-individual variability) and in the same individual, in relation to daily intakes (intra-individual variability), and these are inherent to studies of this type. Moreover, estimated food consumption methods are marked by variations along the evaluation process, from obtaining individuals reported information to the compilation of data. These could lead to a misleading use of data related to food consumption patterns and their association with health outcomes. Third, although the 24-hour recall method is widely used for dietary assessments, the intake of a single day does not represent the daily intake of an individual. However, it has been carefully considered to be the most appropriate and feasible tool regarding both, the purpose of this study and the study population. According to Willett, applying a single 24-hour recall may be suitable for estimating mean intakes in groups, given a sample size that suits this purpose [30].

\section{Conclusions}

This study concludes that the women consumed a low quality diet attributed to the low intake of fruits, vegetables and greeneries and excessive sodium. These inappropriate eating practices have a negative impact on cardiometabolic risk factors of postmenopausal women who also showed a high prevalence of abdominal obesity. Furthermore, women presented increased lipids, fasting glucose as well as higher blood pressure levels that are recognized markers of increased cardiovascular risks.

\section{Competing interests}

The authors declare that they have no competing interests.

\section{Authors' contributions}

DAV, VMF, EGR, LPFM contributed to the conceptualization and design, interpretation and writing of the article. DAV and VMF developed the research protocol and conducted the data collection. EGR were responsible for data analyses. RAGS, CRMMC and MVMP have been involved in drafting the manuscript or revising it critically for important intellectual content. All authors critically reviewed the manuscript, approved the final version submitted for publication.

\section{Authors' information}

DAV is a Nutritionist and has a MSc Degree (Instituto Fernandes Figueira-IFF/ FIOCRUZ); VMF has a PhD in Epidemiology and works in Clinical Research. EGR has a PhD in Biomedical Engineering and works in Clinical Research; LPFM has a PhD in Child and Women's Heath and heads the Endocrinology Department; RAGS has a PhD in Collective Health; CRMMC has a PhD in Internal Medicine and works at Department of Food and Nutrition. MVMP has a PhD in Biomedical Engineering and works in Clinical Research.

\section{Acknowledgement}

Study conducted at the outpatient clinic of Instituto Fernandes Figueira Oswaldo Cruz Foundation (IFF/FIOCRUZ). The research field data used here is part of the Academic Master's thesis of Danyelle de Almeida Ventura, defended and approved at IFF/FIOCRUZ, in March 2013.

\section{Author details}

${ }^{1}$ Instituto Fernandes Figueira (IFF/Fiocruz), Avenida Rui Barbosa, 716-Flamengo, Rio de Janeiro, RJ, Brazil. ${ }^{2}$ University of Mato Grosso, Av. Fernando Corrêa da Costa, n²367-Bairro Boa Esperança, Cuiabá, Mato Grosso, Brazil.

Received: 9 April 2014 Accepted: 15 December 2014 Published: 22 December 2014

\section{References}

1. Fernandes CE, Baracat EC, Lima GR: Climatério: manual de orientação, Federação Brasileira das Sociedades de Ginecologia e Obstetrícia; 2004

2. Toth MJ, Tchernof A, Sites CK, Poehlman ET: Effect of menopausal status on body composition and fat distribution. Int J Obes Relat Metab Disord 2000, 24:226-31.

3. Gambacciani M, Ciaponi M, Cappagli B, De Simone L, Orlandi R, Genazzani AR: Prospective evaluation of body weight and body fat distribution in early postmenopausal women with and without hormonal replacement therapy. Maturita 2001, 39:125-32.

4. Volp ACP, Alfenas RCG, Costa NMB, Minim VPR, Stringuetab PC, Ressan J: Índices dietéticos para avaliação da qualidade de dietas. Rev Nutr 2010, 23(2):281-95.

5. Schmiit ACB: Prevalência da Síndrome Metabólica e Fatores Associados na Transição e após a Menopausa, [Tese de Doutorado]. Pós-Graduação em Saúde Pública. Universidade de São Paulo. Faculdade de Saúde Pública; 2009.

6. Frisancho AR: Anthropometric standards for the assessment of growth and nutritional status. Amm Arbor, Ml: The University Michigan Press; 1990.

7. Lohman TG, Roche AF, Martorell R: Antrophometric Standardization Reference Manual. Champaing: Human Kinetics Books; 1988.

8. World Health Organization (WHO): Obesity: Preventing and managing the global epidemic. Report of a WHO consultation on obesity. Geneva, 3-5 June 1997. Geneva; World Health Organization; 1997. http://whqlibdoc.who. int/hq/1998/WHO_NUT_NCD_98.1_(p1-158).pdf. 
9. Sociedade Brasileira de Cardiologia: VI Diretrizes Brasileiras de Hipertensão. Ara Bras Cardiol 2010, 95(1):1-51.

10. Friedewald WT, Levy RI, Fredrickson DS: Estimation of the concentration of lowdensity lipoprotein cholesterol in plasma, without use of preparative ultracentrifuge. Clin Chem 1972, 18(6):499-502.

11. NCEP Expert Panel on the detection and treatment of high blood pressure in adults: Executive summary of the third report of the National Cholesterol Education Program (NCEP). Adult Treatment Panel III (ATP III). JAMA 2001, 285:2444-9.

12. Centers for Disease Control and Prevention (CDC): http://www.cdc.gov/ nccdphp/dnpa/physical/pdf/PA_Fact_Sheet_OlderAdults.pdf.

13. National Academy of Sciences: Dietary Reference Intakes for Energy, Carbohydrate, Fiber, Fat, Fatty acids, Cholesterol, Protein, and Aminoacids (macronutrients). Washington: National Academy Press; 2005.

14. Brasil. Ministério da Saúde. Secretaria de Atenção à Saúde. Coordenação-Geral da Política de Alimentação e Nutrição: Guia Alimentar para a População Brasileira: promovendo a alimentação saudável, Ministério da Saúde; 2005.

15. Buzzard M: 24-hours dietary recall and food record methods. In Nutritional Epidemiology. Edited by Willett W. Oxford: Oxford University Press; 1998:50-73.

16. Anção MS, Cuppari L, Draibe AS, Sigulem D: Programa de Apoio a Nutrição-NutWin, versão 1.5 [CD ROM]. Departamento de Informática em Saúde-SPDM-UNIFESP/EPM: São Paulo; 2005.

17. Tabela Brasileira de Composição dos alimentos/NEPA-UNICAMP: Versão II-2a ed; 2006. http://www.unicamp.br/nepa/taco/contar/taco_versao2.pdf.

18. Pinheiro ABV, Lacerda EMA, Benzecry EH, Gomes MCS, Costa VM: Tabela para avaliação de consumo em medidas caseiras. 4a Ed. São Paulo: Atheneu; 2000.

19. Fisberg RM, Slater B, Barros RR, de Lima FD, Cesar CLG, Carandina L, Barros MBA, Goldbaum M: Índice de Qualidade da Dieta: avaliação da adaptação e aplicabilidade. Rev Nutr 2004, 17(3):301-8.

20. Philippi ST, Latterza AR, Cruz ATR, Ribeiro LC: Pirâmide alimentar adaptada: guia para escolha dos alimentos. Ver Nutr 1999, 12(1):65-80.

21. Tardivo AP, Nahas-Neto J, Nahas EAP, Maest N, Rodrigues MAH, Orsatti FL: Associations between healthy eating patterns and indicators of metabolic risk in postmenopausal women. Nutr J 2010, 9(64):1-9.

22. Pesquisa de Orçamentos Familiares (POF) 2008-2009: análise do consumo alimentar pessoal no Brasil, Rio de Janeiro. Instituto Brasileiro de Geografia e Estatística (IBGE); 2011. http://www.ibge.gov.br/home/ estatistica/populacao/condicaodevida/pof/2008_2009_analise_consumo/ pofanalise_2008_2009.pdf.

23. Levy-Costa RB, Sichieri R, Pontes NDS, Monteiro CA: Disponibilidade domiciliar de alimentos no Brasil: distribuição e evolução (1974-2003). Rev Saude Publica 2005, 39:530-40.

24. Pereira RA, Andrade RG, Sichieri R: Mudanças no consumo alimentar de mulheres do Município do Rio de Janeiro, Brasil, 1995-2005. Cad Saúde Pública 2009, 25(11):2419-32.

25. Hung H, Joshipura KJ, Jiang R, Hu FB, Hunter D, Smith-Warner SA, Colditz GA, Rosner B, Spiegelman D, Willet WC: Fruit and vegetable intake and risk of major chronic disease. J Natl Cancer Inst 2004, 96(21):1577-84.

26. Perozzo G, Olinto MTA, Dias-da-Costa JS, Henn RL, Sarriera J, Patussi MP: Associação dos padrões alimentares com obesidade geral e abdominal em mulheres residentes no Sul do Brasil. Cad Saude Publica 2008, 24(10):2427-39.

27. França NA, Aldrighi JM, Marucci MFN: Fatores associados à obesidade global e à obesidade abdominal em mulheres na pós-menopausa. Rev Bras Saúde Matern Infant 2008, 8(1):65-73.

28. Martinazzo J, Gabriela PZ, Roseana BS, Vivian PSZ, Giovana CCC: Avaliação nutricional de mulheres no climatério atendidas em um ambulatório de nutrição do norte do Rio Grande do Sul. Revista de Ciência Saúde Coletiva 2013, 18(11):3349-56.

29. De Lorenzi DRS, Basso E, Fagundes PO, Saciloto B: Prevalência de sobrepeso e obesidade no climatério. Rev Bras Ginecol Obstet 2005, 27(8):479-84.

30. Willett WC: Nutritional Epidemiology. Oxford: Oxford University Press; 1998.

doi:10.1186/1475-2891-13-121

Cite this article as: de Almeida Ventura et al: Association between quality of the diet and cardiometabolic risk factors in postmenopausal women. Nutrition Journal 2014 13:121.

\section{Submit your next manuscript to BioMed Central and take full advantage of:}

- Convenient online submission

- Thorough peer review

- No space constraints or color figure charges

- Immediate publication on acceptance

- Inclusion in PubMed, CAS, Scopus and Google Scholar

- Research which is freely available for redistribution 